\title{
ADDITIONS TO OUR KNOWLEDGE OF THE ANTS OF THE GENUS MYRMECOCYSTUS WESMAEL. ${ }^{1}$
}

\section{By William Morton Wheeler.}

Since my paper on the honey ants was published in $1908^{2}$ our knowledge of the distribution of these insects has been increased and two new species have been brought to light. Mr. Percy Leonard of the Raja Yoga Academy at Point Loma, California, has discovered a new subspecies of $\boldsymbol{M}$. melliger and has published an interesting account of its habits and of those of $M$. mexicanus mojave. $^{3}$ During the winter of 1910 I made a second journey to Arizona and California and was able to observe the latter and several of the other subspecies in the field. The discovery of the typical M. mexicanus in Arizona and Southern California by Mr. W. M. Mann, Mr. Leonard and myself brings all of the known species, subspecies and varieties of the genus within the confines of the United States. The separation of these from the Old World forms, till recently regarded as Myrmecocysti, but now placed in Förster's genus Cataglyphis by Emery and Forel, is also an important step in advance, as is also the recognition by the former authority of the fact indicated in my former paper that Myrmecocystus is closely allied to the circumpolar genus Lasius, whereas Cataglyphis is more intimately related to another circumpolar genus, Formica. These diverse relationships of the New and Old World genera are most clearly seen in their respective males. An unsolved problem is still presented by some of the small species of Myrmecocystus and Formica of the subgenus Proformica, such as $M$. lugubris Wheeler of Arizona and P. emma Forel of Algiers, which resemble each other in the most extraordinary manner. This resemblance, however, may be due to convergence of habit, as both are desert ants. Mr. Leonard has found that $M$. melliger lomaënsis has replete, or "honey pot" workers, like the typical

\footnotetext{
${ }^{1}$ Contributions from the Entomological Laboratory of the Bussey Institution, Harvard University, No. 60.

${ }^{2}$ Honey Ants, with a Revision of the American Myrmecocysti. Bull. Amer. Mus. Nat. Hist. XXIV, 1908, pp. 345-397, 28 figs.

${ }^{3}$ The Honey Ants of Point Loma, California. Trans. San Diego Soc. Nat. Hist. I, No. 3, 1911, pp. 85-113, 6 figs.
} 
melliger, but such a physiological caste is still unknown in the subspecies orbiceps, mendax, mimicus and semirufus and in M. iugubris and yuma. All of these seem to be eminently predatory and insectivorous. The repletes of the typical $M$. mexicanus and its subspecies mojave have been studied by Leonard, and it is highly probable that the subspecies navajo presents very similar conditions.

I append a table for the identification of the workers of all the known species, subspecies and varieties of Myrmecocystus with some geographical and ethological notes and with descriptions of the new forms.

\section{Table of Myrmecocystus.}

1. Mandibles 9-toothed; eyes larger; head and thorax and usually also the gaster

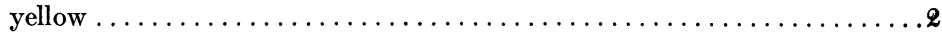

Mandibles 7-toothed; eyes usually smaller; color always darker, head and thorax red or more or less infuscated $\ldots \ldots \ldots \ldots \ldots \ldots \ldots \ldots \ldots \ldots \ldots \ldots \ldots \ldots$

2. Large forms, averaging more than $5 \mathrm{~mm} \ldots \ldots \ldots \ldots \ldots \ldots \ldots$

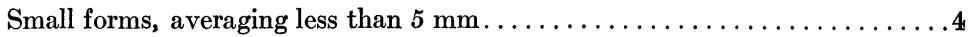

3. Head and thorax sordid yellow, gaster brown or blackish. . mexicanus Wesmael. Head, thorax and gaster pure yellow... . mexicanus var. horti-deorum MacCook.

4. Head narrow; pronotum longer than broad; base of epinotum very convex; erect hairs only on anterior surfaces of antennal scapes. . mexicanus navajo Wheeler.

Head broader; pronotum as broad as long; base of epinotum less convex; whole of antennal scapes with erect hairs..........mexicanus mojave Wheeler.

5. Large forms, averaging more than $4 \mathrm{~mm}$; stature very variable.......6 Small forms, averaging less than $4 \mathrm{~mm}$; stature more constant. . . . . 13

6. Gaster opaque or subopaque, densely pubescent; length $7-9 \mathrm{~mm} . \ldots \ldots \ldots 7$ Gaster shining, with shorter and more dilute pubescence; length $4-6 \mathrm{~mm} .10$

7. Hairs and pubescence grayish, the latter short, not silvery; length 8-9 mm.

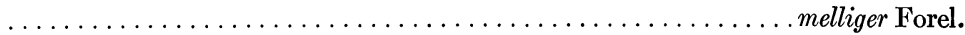
Hairs and pubescence silvery, the latter longer; length $7-8 \mathrm{~mm} \ldots \ldots \ldots 8$

8. Head of largest workers large, orbicular. . . . . . melliger orbiceps Wheeler. Head of largest workers smaller, rectangular. . . . . . . . . . . . .

9. Erect hairs shorter and less abundant, obtuse or subobtuse

$\ldots \ldots \ldots \ldots \ldots \ldots \ldots \ldots \ldots \ldots \ldots \ldots \ldots \ldots \ldots \ldots \ldots$ melliger mendax Wheeler.

Erect hairs longer, more abundant, pointed

melliger mendax var. comatus Wheeler.

10. Erect hairs nearly or quite lacking on antennal scapes. ................. melliger mimicus var. depilis Forel.

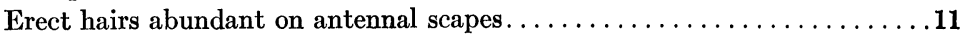


11. Head, thorax, petiole, antennæ and legs uniformly deep brownish red...............................melliger mimicus Wheeler.

Thorax and posterior portion of head usually very dark red or black.

12. Petiole very blunt and rounded above, scarcely compressed anteroposteriorly; color of head and thorax variable. . melliger mimicus var. jesuita Wheeler.

Petiole somewhat more compressed anteroposteriorly; pilosity more abundant; thorax, gaster and posterior portion of head black

.melliger lomaënsis subsp. nov.

13. At least the whole head and thorax light yellowish red .............14

Head and thorax largely black or dark brown. . . . . . . . . . . . . . . . 15

14. Gaster brown, blackish or piceous............ melliger semirufus Emery. Gaster red, like the head and thorax. . . melliger semirufus var. testaceus Emery.

15. Head, thorax and gaster black; head much longer than broad; gula flat or slightly concave ........................ lugubris Wheeler.

Most of the body dark brown; head but little longer than broad, gula convex.

16. Pubescence very short; thorax, gaster and much of the head dark brown; mandibles and anterior border of clypeus and cheeks yellow. . yuma sp. nov.

Pubescence longer and more silvery; yellow of head extending further posteriorly....................... yuma var. flaviceps var. nov.

Myrmecocystus melliger Forel.

Very few United States localities for this ant are cited in my former paper. I have since obtained specimens from the following places:

Texas: Laredo (C. E. Hood); Hondo and Catulla (J. D. Mitchell); Kenedy (G. P. Goll).

Arizona: Huachuca Mts. (C. R. Biederman).

New Mexico: Rito de los Frijoles (T. D. A. Cockerell); Santa Fe (F. C. Pratt).

The specimens from Kenedy, Texas, comprise two ordinary workers, a replete, a male and a winged female. I describe the female and male, because they have not been seen heretofore.

Female. Length $12 \mathrm{~mm}$.

Body stout and broad. Head subrectangular, excluding the mandibles a little broader than long, a little narrower in front than behind, with feebly convex lateral and posterior borders. Eyes but little larger than in the worker major. Thorax considerably broader than the head. Petiole low, more compressed anteroposteriorly than in the worker, its upper border blunt and feebly impressed in the middle. Gaster larger, elliptical, somewhat flattened dorsoventrally. 
Sculpture and pilosity as in the worker major, except that the upper surface of the head is less shining.

Head and lower portions of mesopleuræ and pronotum yellowish red; mandibles, antennæ and legs darker red; remainder of body dark brown. Mandibular teeth black. Wings tinged with yellowish; veins dark brown, stigma paler.

Male. Length $6.5 \mathrm{~mm}$.

Head, excluding the eyes, longer than broad, with very convex eyes and long, slightly concave cheeks. Mandibles with an apical and a rather large, blunt basal tooth. Antennæ slender. Thorax robust. Petiole much compressed anteroposteriorly. Gaster narrow. Wings with well-developed discoidal cell.

Body somewhat more shining than in the worker. Erect hairs whitish, as abundant on the body, scapes and legs as in the worker; pubescence shorter and sparser.

Black; mandibles, anterior border of clypeus and genitalia reddish yellow; thoracic sutures, antennæ and legs brown. Wings whitish hyaline, with pale brown veins and stigma.

M. melliger orbiceps Wheeler.

Texas: Victoria (J. D. Mitchell).

Arizona: Miller and Garden Canyons, Huachuca Mts. (Wheeler)

M. melliger lomaënsis subsp. nov.

Worker. Length 4.5-5.5 mm.

Differing in the shape of the petiole and in color from the worker of the typical form. The petiole is more wedge-shaped and compressed at the superior border. Black; mandibles, cheeks, clypeus, antennæ and legs deep red. Body, and especially the head shining; pilosity and pubescence white, shorter and more dilute than in the typical form and resembling the conditions in mimicus.

Replete. Length 9-10 mm.

Color, especially of the head and thorax, paler and more reddish throughout; in other respects, except for the distention of the gaster, like the ordinary worker.

Female. Length $8.5-9 \mathrm{~mm}$. Wings $12 \mathrm{~mm}$.

Head with straight and less convex sides than in the female melliger, as long as broad. Eyes more convex. Petiole cuneate in profile, with flat anterior and posterior surfaces and rather sharp superior border, which is distinctly emarginate in the middle.

Sculpture, pilosity and pubescence as in the worker.

Black; gula, corners of clypeus and mandibles, except the teeth, antennal scapes and legs dark reddish brown; median funicular joints sometimes paler and more yellowish. Wings whitish hyaline; veins and stigma pale yellow; first longitudinal vein blackish.

Described from six workers, three repletes and two females taken by Mr. Percy Leonard on Point Loma, near San Diego, California. 
This subspecies is closely related to the subspecies mimicus, but the petiole of the worker is more compressed anteroposteriorly and less blunt at the margin, and the color, especially of the head, is much darker in both worker and female. The wings of the female are fully $1 \mathrm{~mm}$. longer, the erect hairs are sparser and more delicate, and the pubescence of both worker and female is more dilute.

Leonard says that this ant "is strictly diurnal in its habits and has been seen feeding upon the white flowers of Mesembryanthemum cquilaterale."

M. melliger mimicus Wheeler.

I have taken specimens of this widely distributed desert ant at Benson, Arizona, and have received a series of workers, males and females from Kennedy, New Mexico (W. D. Hunter) and several workers from Riverside and Whittier, California (K. J. Quayle).

\section{M. melliger semirufus Emery.}

This small, light-colored form is common in sandy spots in the desert about Yuma, Arizona. It has also been taken by Mr. P. Leonard at Point Loma, Cala. The specimens from the latter locality have the head and thorax somewhat darker than the Arizona specimens and the gaster reddish at the base, so that they are transitional to the var. testaceus Emery.

\section{M. lugubris Wheeler.}

This species bears a striking resemblance to certain Formicas of the subgenus Proformica, notably to $P$. emme recently discovered by Forel in the deserts of Algiers. The structure of the maxillary palpi and the shallower mesoëpinotal constriction alone indicate that the Arizona species is a Myrmecocystus. To my description (Journ. N. Y. Ent. Soc. XVII, 1909, p. 98) I would add that the gula is flattened or slightly concave when seen in profile.

\section{M. yuma sp. nov.}

Worker. Length 2.5-3.5 mm.

Allied to lugubris; monomorphic. Head only slightly longer than broad, convex above and below, distinctly broader behind than in front, with broadly rounded 
lateral and posterior borders. Eyes very convex, fully half as long as the cheeks. Ocelli minute. Mandibles 7-toothed, with the apical tooth longest and curved. Clypeus convex but not carinate in the middle, flattened and depressed on the sides. Frontal area distinct. Antennæ moderately slender, scapes extending about 2/5 their length beyond the posterior border of the head. Thorax much as in the other species of the genus; pronotum as broad as long; mesoëpinotal constriction shallow; epinotum with subequal base and declivity, bluntly angular. Petiole half as broad as the epinotum, cuneate in profile, inclined forward, compressed anteroposteriorly, with flattened posterior and feebly convex anterior surface and blunt border, which, seen from behind, is straight and entire. Gaster and legs of the usual conformation.

Mandibles subopaque, densely and finely striated. Clypeus and head very smooth and shining. Thorax and gaster more opaque, especially on the dorsal surface, finely shagreened.

Hairs and pubescence white, the former short, erect, absent or very sparse on the scapes, moderately abundant on the head, somewhat sparser on the thorax and gaster, short, sparse and reclinate on the tibiæ. Pubescence short and delicate, moderately abundant on the head, thorax, gaster and appendages.

Dark brown; anterior half of head, antennæ, palpi and legs paler; mandibles, anterior border of clypeus and cheeks, tibiæ and tarsi yellowish or pale brown. Mandibular teeth black.

Described from numerous workers taken from several colonies at Yuma, Arizona.

This species differs from lugubris in the shape of the head and petiole, from the various forms of melliger in its much smaller size and in the inclination and shape of its petiole.

$M$. yuma inhabits small crater nests, 3-4 inches in diameter, in the pebbly desert. The nest entrance is small, often less than $1 / 4$ in. in diameter and often surrounded by small twigs and dead leaves. The numerous remains of small insects, frequently seen around the edges of the craters, show that this ant is predatory in its habits. The colonies are quite populous so that they cannot be regarded as incipient colonies of any of the subspecies or varieties of $M$. melliger. At first sight $M$. yuma may be readily mistaken for the small desert form of Dorymyrmex pyramicus Roger var. niger Pergande.

\section{M. yuma var. flaviceps var. nov.}

Worker. Length 2.5-3.5 mm.

Differing from the typical form in color and pubescence and in having the head more rectangular and broader in front. The brown coloration of the body and appendages is paler and the yellow color on the head extends back over the gula 
and cheeks and often also over the clypeus and front. Palpi yellow. The white pubescence, especially on the thorax, gaster and posterior portion of the head is much longer and more silvery. The anterior surfaces of the antennal scapes have a row of erect hairs.

Described from numerous workers taken from several colonies at Yuma, Arizona, in the same localities as the preceding.

The craters of this variety are larger than those of the typical yuma, measuring 6-8 in. in diameter, with entrances nearly $\frac{1}{2}$ in. across. These nests are also more populous. The precise relations of this variety to yuma and to the smaller forms of melliger (semirufus and testaceus) cannot be determined till the sexual phases have been discovered. Perhaps flaviceps will then have to rank as an independent species.

M. mexicanus Wesmael.

Until recently the typical form of this species was not known to occur within the United States. During August 1910 it was discovered in the desert about Hereford in Southern Arizona by Mr. W. M. Mann. Early in November of the same year I found it in the same locality, and Mr. P. Leonard simultaneously found it on Point Loma, near San Diego, California. So far as known, therefore, it is confined to Mexico and the extreme southern boundary of the United States. It is a less handsome form than the variety horti-deorum, as the yellow of the head and thorax and the brown of the gaster have a dirty grayish tint. Besides these differences in coloration I can detect no others of importance between the two forms.

The nests of mexicanus at Hereford are not abundant. They resemble those of the variety horti-deorum but are in adobe soil, so hard that I was unable to excavate it to a depth sufficient to expose the honey chambers. Mr. Leonard was more successful at Point Loma. He gives an interesting account of the nests and of the habits of this ant and its repletes (loc. cit.).

M. mexicanus var. horti-deorum McCook.

The range of this variety, which was formerly known to occur only in Colorado and New Mexico, has been considerably extended of late. The locality "California" given in my paper (loc. cit. 
p. 359) on MacCook's authority, probably refers to the subspecies mojave (vide infra). During November 1910 I found a single colony of horti-deorum in Miller Canyon, Huachuca Mts., Arizona, at an altitude of about 5,600 ft., and Mr. A. O. Garrett has taken it at Garfield, Utah, near the southern end of Great Salt Lake. This is the most northern point at which any of our Myrmecocysti have been taken.

M. mexicanus navajo Wheeler.

The types of this subspecies which is easily distinguished by its small size, the much greater convexity of the base of the epinotum and the erect hairs only on the anterior surfaces of the antennal scapes, are from Albuquerque, New Mexico. I have recently received a number of workers, which agree in all respects with the types, from Kennedy in the same state (W. D. Hunter).

M. mexicanus mojave Wheeler.

The discovery of the males and females by Mr. P. Leonard at Point Loma, Cala., shows that this subspecies is very clearly marked. It was found some years ago at Pasadena, Cala., by Mrs. Elizabeth Grinnell, who kindly permits me to publish a photograph which she took of a number of living repletes (Fig. 1). Winged females have been taken by Mr. C. F. Baker at Claremont, Cala., and during December, 1910, I found numerous colonies containing workers and males, on the grounds of Pomona College in the same locality. As my original account of the worker is very brief I give a somewhat more explicit description in connection with that of the other unpublished phases.

Worker. Length 4.5-5 mm.

Head only slightly longer than broad, subrectangular, but little narrower in front than behind, with rather straight sides. Mandibles short and rather convex. Eyes large and convex, more than half as long as the cheeks. Mesonotum and neck of pronotum distinctly shorter than in the other forms of mexicanus, the pronotum being as broad as long. Base of epinotum more convex than in mexicanus and horti-deorum but less convex than in navajo. Border of petiole somewhat less blunt than in the other forms, its border sometimes impressed or feebly excised in the middle.

Body a little more opaque and pubescence and pilosity somewhat more abundant than in horti-deorum; coloration, especially of the gaster, more sordid or brownish yellow. In some specimens the gaster is uniformly brown. Head reddish behind; antennæ, palpi and legs pale or whitish yellow. 
Replete. Length 7-10 mm.

Like the ordinary worker, except in the great distention of the gaster and the more brownish tint of the posterior portion of the head, thoracic dorsum and gastric sclerites.

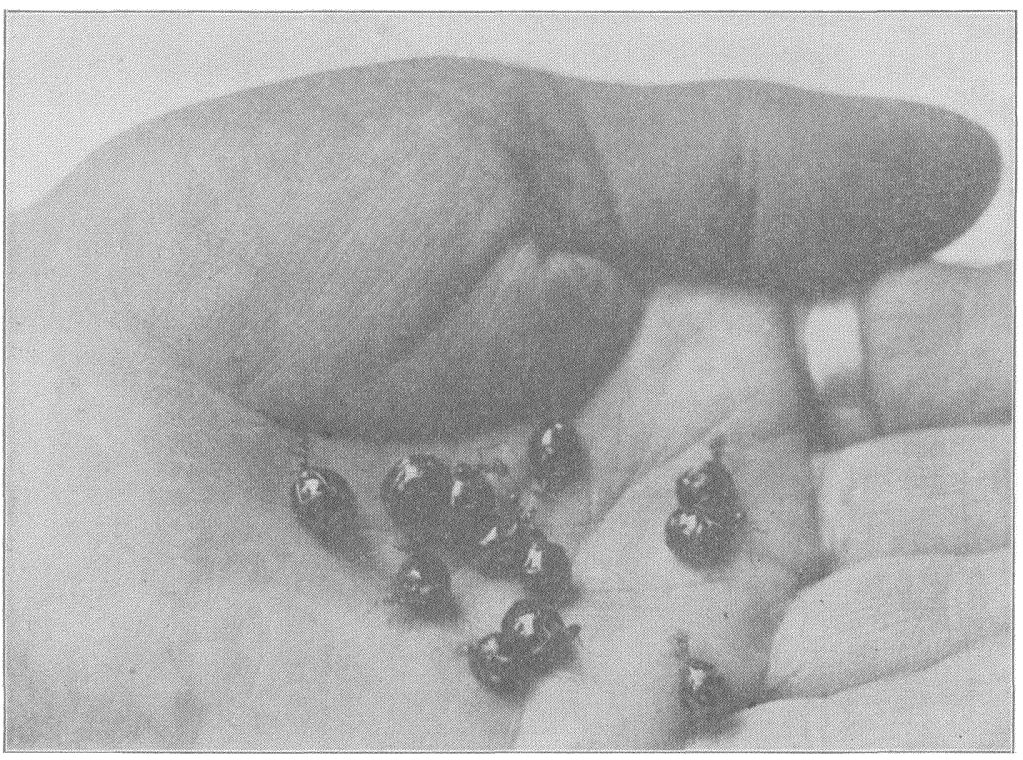

Fig. 1. Repletes of Myrmecocystus mexicanus mojave Wheeler. (From a photograph by Mrs. Elizabeth Grinnell).

Female. Length 8-10 mm. Wings $12 \mathrm{~mm}$.

Differing from the female of horti-deorum in the following characters: cheeks somewhat more, eyes somewhat less convex. Petiole much more compressed anteroposteriorly, with a sharper and much more deeply excised border. Body dark brown; thorax and posterior portion of head nearly black; anterior half of head, venter and thoracic sutures paler and more reddish; mandibles, except the teeth, antennæ and legs yellow or pale brown. Stigma and veins of wings dark brown. Erect hairs on the body and appendages somewhat more abundant than in horti-deorum.

Male. Length 4-5 mm.

Differing from the male of horti-deorum in having the head broader, the mandibles shorter, with broader blades, and the head, thorax and gaster dark brown or blackish, with the mandibles, antennal scapes, legs and genitalia somewhat paler, the funiculi and tarsi yellowish. The erect hairs on the body are distinctly longer, coarser and more abundant. 
At Claremont, Cala., where I hurriedly examined some 20 nests of this ant, I found the craters to vary from 4-8 inches in diameter, with a central opening $\frac{1}{4}-\frac{3}{4}$ of an inch across. They were in dry, hard soil, often along roads or paths in situations where there was considerable vegetation, either chaparral, live-oaks (Quercus agrifolia) or scrub-oaks ( $Q$. dumosa). In such localities the ants probably obtain their supply of nectar from the galls or from coccids and aphids on the oaks or other components of the chaparral. Mr. Leonard has given a more extensive account of the habits of mojave at Point Loma. He found that it is nocturnal like horti-deorum and that it visits aphids on carnations and roses, and the nectaries of the pepper tree (Schinus molle), rattle-snake weed (Euphorbia setiloba), honey plant (Echium simplex) and Ceanothus cuneatus. The last is a well-known element of the Californian chaparral.

\section{THE NORTH AMERICAN SPECIES OF THE GENUS HAMATOPOTA.}

\section{By Charles W. Johnson.}

In the Eastern United States the species of this genus are comparatively scarce, and in all my collecting I have taken only two specimens. Under such circumstances it is often very difficult positively to determine an inadequately described species of the older authors: thus the only species collected in this region was naturally referred to $H$. punctulata Macq., described from Carolina. In preparing recently a faunal paper on the diptera of Florida, my attention was called to four specimens collected by Mrs. Annie T. Slosson, which were very different from Pennsylvania and New Jersey specimens which I had referred to Macquart's species. A careful study shows that the Florida specimens are undoubtedly the true $H$. punctulata, while the more Northern specimens represent a new species. The species may be tabulated as follows:

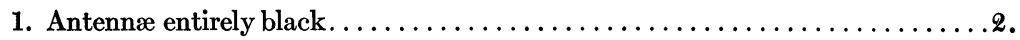
Antennæ with the third joint (except the annuli) red. Front with two subquadrate black spots. Apical band of the wing broad and distinct from the anterior to the posterior margin.................... 

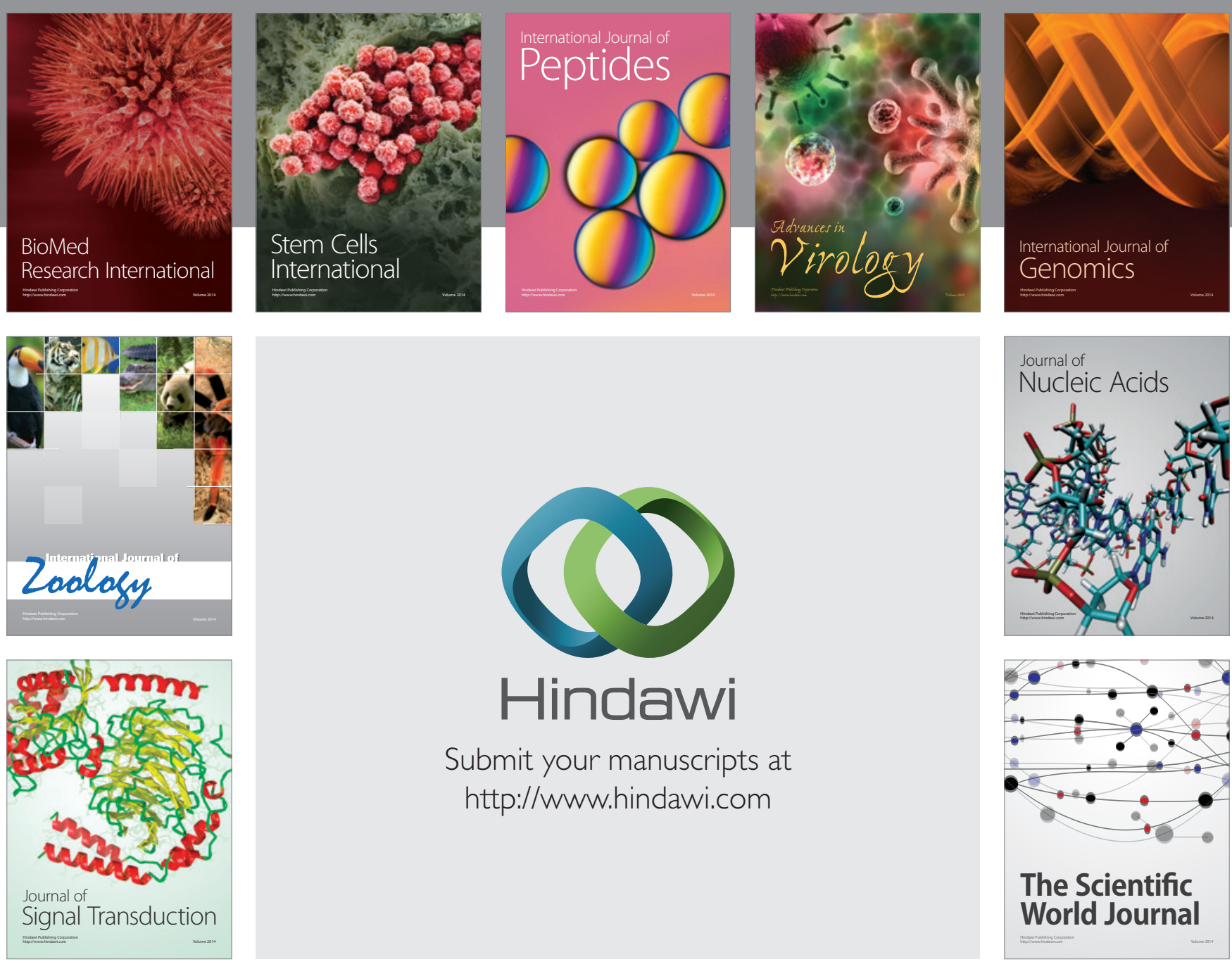

Submit your manuscripts at

http://www.hindawi.com
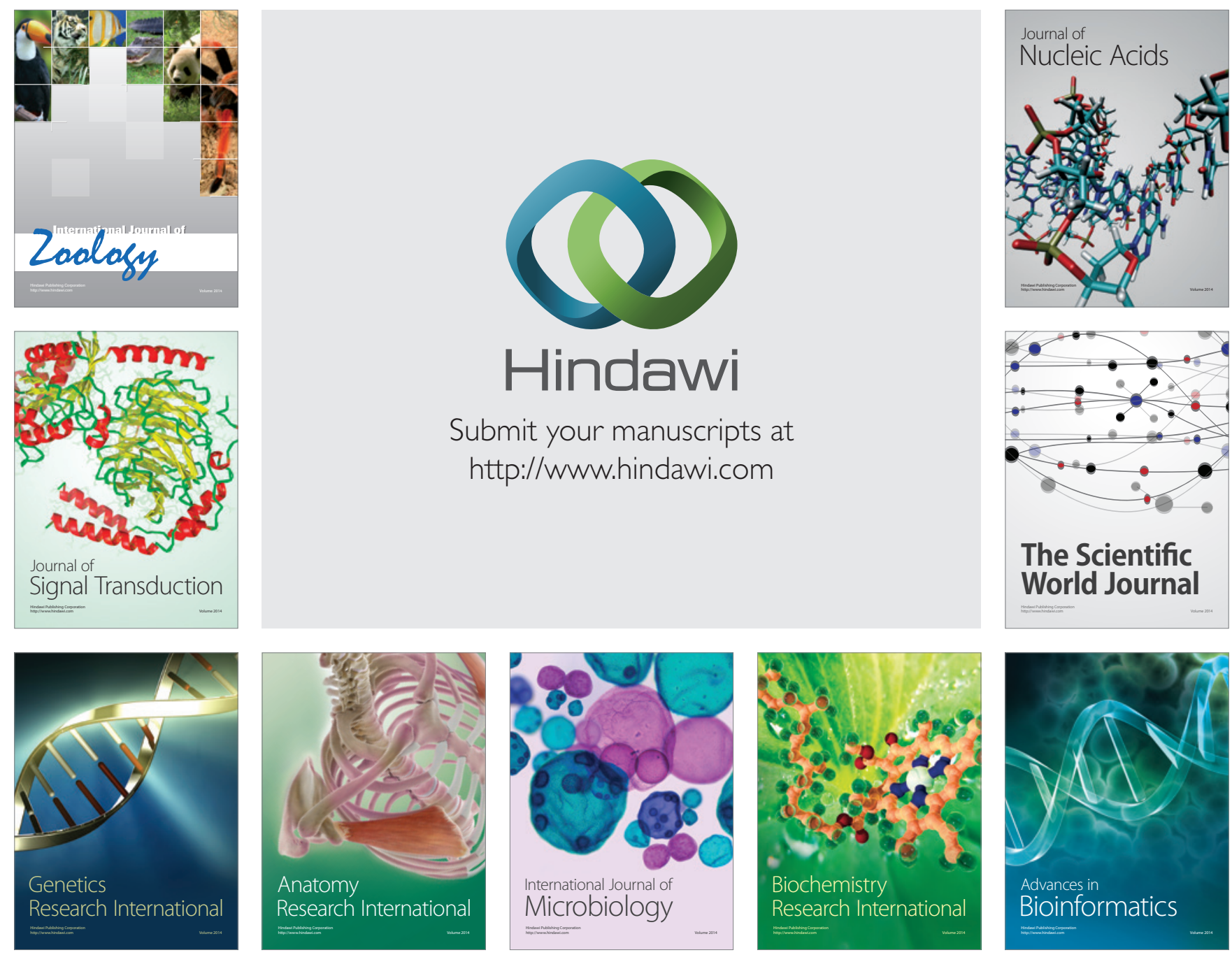

The Scientific World Journal
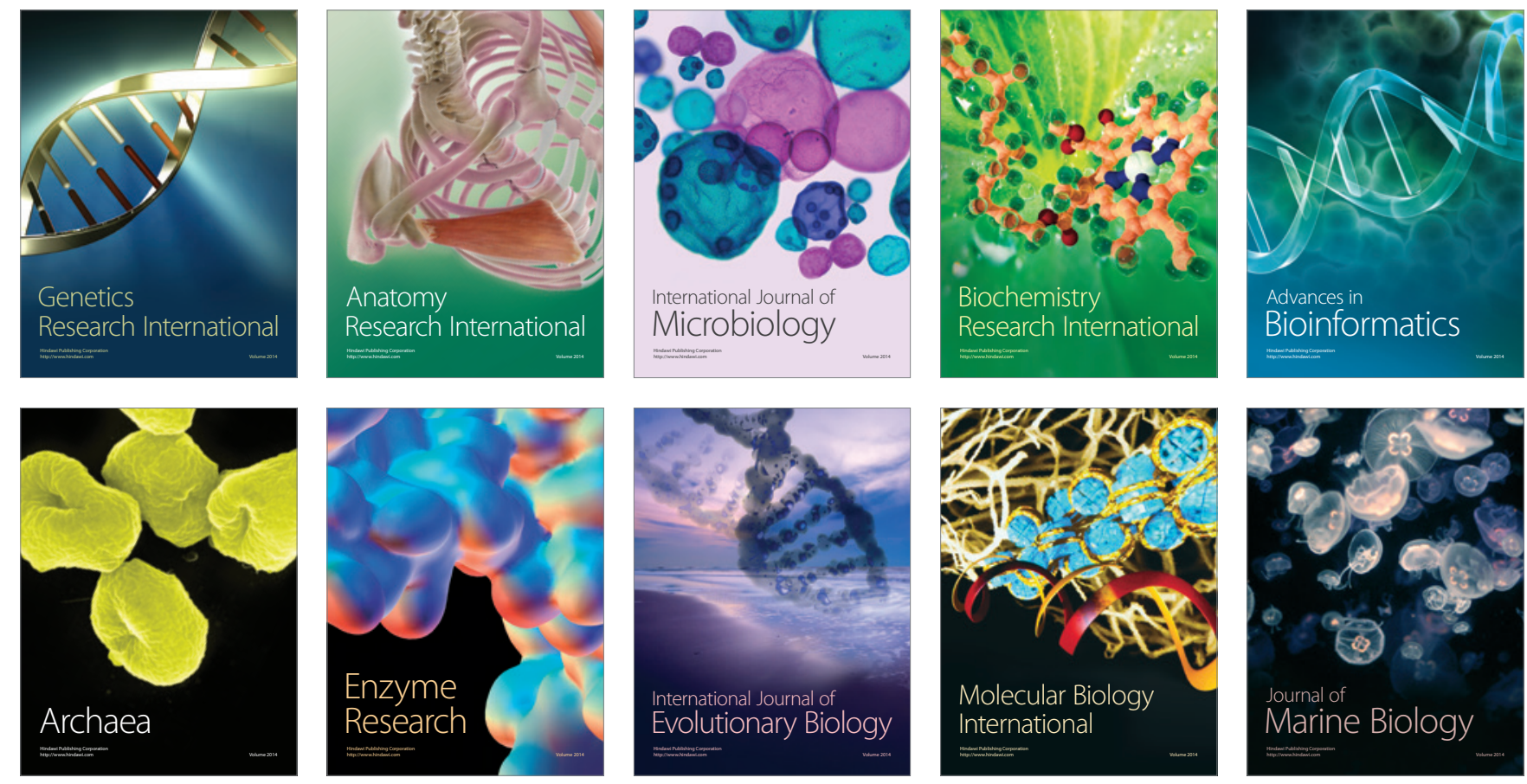